\title{
Rationalities in the pedagogical regime of practice
}

Falster, Emil Søbjerg; Warming, Hanne

\section{Published in:}

Childhood

DOI:

10.1177/0907568219869805

\section{Publication date:}

2019

Document Version

Peer reviewed version

Citation for published version (APA):

Falster, E. S., \& Warming, H. (2019). Rationalities in the pedagogical regime of practice. Childhood, 26(4), 554569. https://doi.org/10.1177/0907568219869805

\section{General rights}

Copyright and moral rights for the publications made accessible in the public portal are retained by the authors and/or other copyright owners and it is a condition of accessing publications that users recognise and abide by the legal requirements associated with these rights.

- Users may download and print one copy of any publication from the public portal for the purpose of private study or research.

- You may not further distribute the material or use it for any profit-making activity or commercial gain.

- You may freely distribute the URL identifying the publication in the public portal.

Take down policy

If you believe that this document breaches copyright please contact rucforsk@kb.dk providing details, and we will remove access to the work immediately and investigate your claim. 


\title{
Rationalities in the pedagogical regime of practice
}

\begin{abstract}
Using a Foucauldian governmentality approach, this article examines the connections and tensions between rationalities relying on recognition and democratic ideals, and the educationally- and developmentally-oriented rationality that characterises the pedagogical regime of practice in Denmark. The conclusion is that rationalities of recognition and democracy are subordinated to an educationally- and developmentally-oriented rationality. Thus, in practice the former are transformed into an instrument for fulfilling educational and developmental objectives, with a primary focus on the child achieving an age-appropriate level of development.
\end{abstract}

\section{Keywords}

Early childhood education, governmentality, recognition, developmental psychology, children's participation.

This article explores rationalities in pedagogical work in day care institutions for young children in Denmark. It examines how these rationalities, and their related power relations, impact pedagogy, and thereby shape the space available for the recognition of children's perspectives and participation. The article draws on the insight that childhood is a social phenomenon, and hence it regards the aims of child care, and approaches to it, both as emerging from socially constructed images of children that interact with other societal characteristics, trends and changes; and as contributing to the positioning of children in the generational order (Qvortrup 2009, Alanen 2009).

In globalised societies in which national governments identify and act as competition states (Cerny, 1997; Jessop, 2002) or investment states (Giddens, 1998; Esping-Andersen et al., 2002), increasing attention is being paid to young children (who are regarded as human raw material), and by extension to early childhood education, with a view to optimising the potential of children as future citizens (Lister 2004, Bühler-Niederberger \& Sunker 2009; Ailwood, 2010; Lee \& Motzkau, 2011; Warming, 2018a). Simultaneously, there is growing acknowledgement of children as beings and rights bearers, and a resulting engagement with children's perspectives (Wyness, 2018; Warming, 2018b). Denmark, together with the other 
Nordic countries, is often singled out as an exemplary case which other countries might learn from, due to its long tradition of high coverage of children in day care, improvement of children's wellbeing, and recognition of children's perspectives (see e.g. Devine \& Kilkelly 2011 and Sylva 2010). However, critical voices in Denmark have also claimed that these institutions are - or have been - more about the 'storage' of children than about education and development (Reksten \& Jørgensen 1996). This critique - which has fed into an intensive governmentalisation of the field in the form of national curricula, documentation requirements, and municipal implementation of various imported educational programmes and approaches stems from a pedagogical position in which education is conceptualised in terms of structured, adult learning.

Throughout the last century, pedagogy in Danish day care institutions was inspired by Fröbel's reform pedagogy (Fröbel 1895/1985), where the primary idea is that children learn best through free play rather than by being taught strictly in line with curricula (Kampmann \& Nielsen 2004). This contrasts starkly with the ideology behind the above-mentioned critique. The new governmentalisation of the field challenges this pedagogical approach, although not for the first time. During the 70's, and to some extent also during the 80 's, reform pedagogy was challenged and partly replaced by Soviet-inspired 'structured pedagogy' which aimed to enhance children's social competences and prepare them for 'the real world' using structured adult activities (ibid). However, this pedagogical trend didn't last long, as a new alliance between reform pedagogy and ideas from the new social studies of childhood during the 80's and 90's challenged 'structured pedagogy' through critique and by proposing alternatives. Thus, the focus on children's own initiatives and engagement was renewed, now with the explicit intention of involving children's perspectives for democratic and ethical reasons (Warming, 2011). Together with the critique of total institutions (Goffman 1961), which has also found its way into the Danish day care field (see Sigsgaard et al. 1998), this resulted in attempts to deinstitutionalise and democratise for the purpose of enhancing children's wellbeing, as well as in initiatives to create a homelike and inclusive environment with a focus on the individual child, allowing space and support for his/her individuality.

The pedagogical landscape has thus changed several times, but recently further changes have been quite intensively initiated by the government. This is not only the case in Denmark and the other Nordic countries, but is a more widespread phenomenon, as least across Europe 
(Bahle 2009). In this article, we examine these changes in Denmark based on a qualitative case study analysed using a Foucault- and Rose-inspired approach.

Several Foucauldian-inspired childhood researchers have explored these changes in the pedagogical landscape and the governmentality that children are subjected to. They have demonstrated how the 'government of children' and the concept of governmentality are useful theoretical approaches for analysing such changes (e.g. Hultqvist, 1997; Hultqvist and Dahlberg, 2001; Dahlberg and Moss, 2005; Smith, 2011; 2014). Nicolas Rose (1999) further developed this approach in the related perspective known as 'advanced liberalism'. This has resulted in several studies which investigate the neoliberal government of children. Thus, Parton (1998) finds that neoliberal governments have shifted towards a focus on the management of risks that children might bear. He argues that this will change the pedagogical profession and its work, so that the primary focus will be on the identification and elimination of risk at the expense of other goals. In two other studies, Ailwood (2004; 2008) shows how the rationalities that children and adults are governed by aim to produce and mobilise capacities that prepare the child for lifelong learning and earning. The goal is to produce a child that can be part of the workforce in the future. Likewise, Lee (2001) finds that the government of children turns the state into a "developmental state" whose primary task is to shape children in order to secure the economic future of society (Lee and Motzkau, 2011).

The above-mentioned studies implicitly identify a political rationality that advocates the futureproofing of society though the intensive government of children. Children are thereby reduced to being the raw material of their future societal function. Moreover, the child figures as a passive object that must be shaped and educated. Thus, in these rationalities, the child's participation, both as a democratic right and in the form of co-creation and resistance, appears to be ignored. However, a different perspective is given in Redmond's (2010) study of welfare reforms in the West. According to Redmond, children are constantly seen as "experts in their own lives", which fundamentally makes them responsible. Redmond suggests that this will mobilise certain capacities in children that society will take advantage of, because power is mediated through children, thereby affecting parents' self-government. Haldar and Engebretsen (2013) offer the same conclusion in their study of so-called 'teddy-diaries'.

Summed up, these studies thematise the idea that the new political rationalities both address children as passive objects over whom power is executed; and as active subjects through whom 
power is mediated. Although taken together, these studies provide a fairly comprehensive picture of the plurality of rationalities of government that exist on different levels and in different national contexts, few studies analyse the coexistence of, and power relations between, several rationalities in a single context. Fewer still explore how these various rationalities support or work against each other in the pedagogical regime of practice, which is the focus of this article.

We start out by introducing the concepts of 'political' and 'governmental' rationalities, respectively, as well as practice regimes, which are central to our analysis. We then describe our data and methods. Next, we describe the three main rationalities, and analyse how they manifest in different articulations of daily work with children. First, the developmental rationality is analysed as an example of a political rationality. Second, we analyse two different governmental rationalities: the participation rationality and the relational rationality. Finally, we analyse the connections and tensions between these rationalities, and the opportunities and limitations they create in the pedagogical regime of practice.

\section{Rationalities in action in practice regimes}

This section introduces a distinction between political and governmental rationalities. The first refers to how government affects governmental authorities and organs, such as pedagogues; while the second does not necessarily refer to a government but can be constituted and modified in internal contexts such as day care institutions. Based on Foucault's analysis of the transformation of the modern state's use of power from repressive enforcement to 'government' (Foucault, 1991; 1983; 1984), Rose and Miller (1990, 1992) develop the concept of political rationalities as a means to analyse government in the sense of the "conduct of conduct". Political rationalities are characterised by the following:

1) They have a moral form that defines the aims of government, the ideals and principles that underpin these aims, and the tasks that certain authorities can legitimately perform (e.g. the pedagogical profession should ensure children's development and learning).

2) They rely on epistemological assumptions about, and characterisations of, what and who must be guided and managed, particularly those who are objects of different 
governmental strategies (e.g. children in the educational system or children with certain rights).

3) They use a distinctive idiom which addresses the reality and the object of government in such a way that its aims, ideals and principles are realised (e.g. developmentalpsychological instruments that are used to measure and evaluate children's development and learning).

Political rationalities are governmental rationalities if they contain reflections and calculations about the way in which certain objects are governed. However, they are also characterised by their unambiguous focus on sustaining the government's power, influencing the way that governmental authorities and organs exercise power in their daily work, and ensuring that the state can take advantage of this (Dean, 1999: 210). What distinguishes governmental rationalities from political rationalities is that these can involve:

"... any form of thinking which strives to be relatively clear, systematic and explicit about aspects of 'external' or 'internal' existence, about how things are or how they ought to be"

(Dean, 1999: 11).

Rationalities should be related to the particular practice regime where they exist, function and operate. The regime of practice is therefore the analytical level where we identify and analyse the connections and tensions between rationalities, and how these affect ways of thinking and behaving that create certain subject positions (Dean, 1999).

'Practice' is not understood as something that is formed by an institution or a specific ideology; rather, it is something that: "...up to a point [has its] own specific regularities, logic, strategy, self-evidence and reason" (Foucault, 1991a: 75). The definition of practice must be combined with Foucault's definition of regimes, which is why our analysis addresses regimes of practice, which are described as: "places where what is said and what is done, rules imposed and reasons given, the planned and the taken for granted meet and interconnect" (Foucault, 1991a: 75). Based on the pedagogues' verbal articulations, we analyse how different rationalities meet, interconnect, cooperate and oppose each other, and which opportunities and limitations this creates in practice. 


\section{Data and method}

Empirically, we base our analysis on a case study of two day care institutions in Denmark. We regard these institutions as extreme and critical cases, following Flyvberg (2006). He defines extreme and critical cases as "the 'most likely' or 'least likely' case; that is, cases which are likely to either clearly confirm or irrefutably falsify propositions and hypotheses (Ibid: 14). We regard our cases as extreme and critical in regard to the hypothesis that a fundamental shift is taking place away from reform pedagogy, since management and staff at the institutions in question were very reflexive about their pedagogy and explicitly expressed their aim to recognise children's perspectives and participation. Thus, our cases are atypical examples of what is possible within the pedagogical field in Denmark, with its history and ongoing changes. Flyvbjerg argues that "atypical or extreme cases often reveal more information because they activate more actors and more basic mechanisms in the situation studied" (Flyvbjerg 2006: $13)$.

The analysis is based on two focus group interviews with staff members, individual semistructured interviews with the head of each of the institutions, and documents. In each focus group, four pedagogues participated: two persons from the section for children aged 0-3 years, and two persons from the section for children aged 3-6 years, respectively. The documents include legislation (Retsinformation, 2015, 2015a), the institutions' own descriptions of their aims, purpose, values, theoretical approaches, methods and instruments, as well as different evaluations and descriptions of practices. We analyse these documents with a view to identifying different political and governmental rationalities at play at the national and local government institutional level. This informs our analysis of whether and how these rationalities are at work in staff members' verbal articulations of practice.

In the following, we describe the three main rationalities and analyse how they manifest and are linked to different kinds of knowledge in daily work. First, the developmental rationality is analysed as an example of a political rationality. Second, we analyse two different governmental rationalities, respectively: the participation rationality and the relational rationality. Finally, we analyse the connections and tensions between the rationalities, and the opportunities and limitations they create for daily work with children.

\section{The developmental rationality}


In this section, we analyse how the nursery curriculum and assessment instruments can be regarded as manifestations of an external development rationality that reduces pedagogical work to a focus on children's age-appropriate development; and we examine how this rationality is implemented in practice. Our analysis starts with legislation, as this underpins the regulation of the institutions in question.

Particularly interesting is the law from 2004 that introduced state-defined curricula for early day care (Retsinformation, 2015), marking a radical shift away from the decentralised identification of pedagogical aims by municipalities or institutions and towards aims determined by the state (Broström, 2007). The law dictates that all day care institutions must prepare one curriculum for children aged 0-2 years, and one for children aged between 3 years and the age of school start (Retsinformation, 2015). In these curricula, the institutions have to describe their educational/pedagogical learning objectives under the following six themes:

1. Versatile personal development.

2. Social skills/competences.

3. Linguistic development.

4. Body and movement.

5. Nature and natural phenomena.

6. Cultural forms of expression and values.

Each theme must be accompanied by a description of how the institution meets the various objectives, and how the work with each theme is evaluated (Retsinformation, 2015a). In this way, the curriculum is an instrument that addresses the moral dimension of the political rationality whereby objectives, ideals and values are clarified to the pedagogues. A pedagogue described this as follows:

"It's [the curriculum] something fundamental that constantly forms the basis of the work, it is the starting point in relation to which part of the child's development we must take care of".

In both institutions, the pedagogues describe the curriculum as a fundamental basis and starting point for their daily work, and as the criterion that defines what activities are considered relevant. The curriculum constructs a particular framing of pedagogical practice in which the child's development, notably its next developmental stage and learning level, become the primary objective. This becomes clear in the pedagogues' basic attitudes to that work, which 
reveal that the support and development of the child's competence acquisition are viewed as the primary objectives. One pedagogue said:

"Everything we do is to prepare for the child's development, for a life they know and can follow, and then develop the skills they need, depending on their age and what goals they have next".

Besides stating that these objectives are anchored in daily practices, this quotation is also an expression of epistemological assumptions about the object of power. These assumptions are concentrated around the child, and around specifically selected skills that depend on a given competence and age classification of the child. The epistemological realisation of the objectives in question therefore rests on a series of assumptions about the skill set that a child must have by a certain age. One of the pedagogues put it this way in relation to the curriculum:

"Sometimes it creates challenges because there may be cases or periods where we haven't been so much into a theme, e.g. motor skills, and then we need to rectify that before we evaluate the curriculum, so in that way the curriculum manages much of the work".

Pedagogy is thereby transformed into a functional didactic in which pedagogical ideals are rooted in a belief that daily pedagogical work must shape children to become resources for future society. Or as one of the pedagogues said: to produce "personal well-being, development, learning and health, so that they [the children] achieve the best possible qualifications for an independently adult life”. This is supported by developmental psychology assessment instruments, which the institutions use to measure and assess each child's development. Some municipalities establish mandatory instruments to support the municipality's overall child policy and the general framework provided by the state, but this is not the case for our case institutions. They have chosen to use the instruments themselves.

One of our case institutions uses the Wheel of Competency Assessment (WCA), which is a circle divided into six sections. Each section corresponds to one competence, and each competence contains several sub-competences. The six main competences are:

1. Personal - e.g. feelings, self-esteem and association.

2. Body - e.g. fine/gross motor skills, nutrition and health. 
3. Language - e.g. listen, talk, vocabulary and communication.

4. Nature - e.g. terms, attention, actions and relationship to nature.

5. Culture - e.g. music, drama and figurative language.

6. Social - e.g. social behaviour and relations.

Based on the WCA, the pedagogues assess whether the child has acquired these competences, and whether its development in regard to each competence dimension is age appropriate. This is a simplified description, however, as it contains a large number of different sub-competences with several explanations for each competence. The WCA is a complex abstraction in which almost all elements of a child's development, competences, learning, behaviour and relations to its surroundings are objectified and systematised for the pedagogues to use. The WCA draws its theoretical inspiration from Daniel Stern's developmental psychology and Lev S. Vygotsky's learning psychology (LearnLab, 2019). Vygotsky is known for the theory of "the zone of proximal development" where it is assumed that the child is located in a current zone of development and can, with the proper exposure, move towards its potential zone of development. The child's development and learning is therefore not just supported from a hereand-now perspective, as the pedagogues have to guide the child towards its potential and future zone of development. Thus, a new zone and a new goal always exist towards which the child must be guided and led.

The WCA exemplifies the way in which the rationality in question seeks to shape reality and guide the work with the children towards optimising the child's competence acquisition and linear movement towards the next zone of development. This means that the instrument conceptualises those latent objects in the child that must be managed, in order to realise and achieve the objectives of the developmental rationality. The six competences are directly coincident with the six themes in the curriculum, which show how the rationality mobilises self-government by the pedagogues, because the institutions implement and use instruments that can fulfil the curricular objectives. The pedagogues find the instrument helpful:

"It's so easy, because the child is placed on a scale and then we can monitor the child's development and that's just the way it is. If something is lagging behind, then we can put in an effort"

The rationality's moral form and ambitions are operationalised into practical demands and methods (or instruments) of performance optimisation. Since the pedagogues find it helpful to 
assess and evaluate each child's performance, and relate it to their own efforts, this appears to shape their pedagogical practice.

\section{The relational rationality}

The institutional goal is to ensure that children's relationships with adults support their development. This goal rests on a scientifically founded perspective, namely Stern's theory about the child's development of self-senses (Stern, 1995). This theory emphasises that the child's development is realised through a supportive relationship to its caregivers, characterised by affective attunement. Through this, the child comes to know the caregivers' reactions as a direct extension of its own behaviour, and is thereby affirmed (Wedel-Brandt, 2008). Thus, the broad intention behind this rationality is to mobilise development-supporting interactions with the children for the purpose of the child's movement towards the next zone of development and, according to this rationality, this is the pedagogues' responsibility.

\section{The primary adult technology}

One example of how this rationality influences daily practices is the so-called primary adult function, which means that one specific pedagogue is the child's primary caregiver and the parents' reference point vis-à-vis the institution. This pedagogue pays particular attention to the child from the beginning, conducts a start-up meeting with its parents, and arranges a follow-up meeting after a month. At these meetings, the parents must deliver special knowledge about their child. First, knowledge is sought concerning the child's sleeping and diet routines, for example, how the child sleeps, signs of tiredness, which foods the child does not eat, if the child is breastfed at home, and how the child displays signs of hunger and thirst. Second, the parents must provide general information about the child. For example, if the child suffers from any illnesses or allergies, if the child has motor skill problems, what makes the child happy/sad, and what works best in terms of comforting the child. The parents are also invited to provide general information about the child's health, religion, family relations and other special considerations. With this information, the pedagogues are able to mobilise an intimate relationship with the child that rests on concrete knowledge about him or her, so that their relational work may be performed in the best way possible. However, this approach also establishes certain power relations between the pedagogue, the child and its parents, because the theory is assumed to factually explain how children's early development progresses, and how the pedagogues are supporting this. Thus, the theory that underpins this rationality defines 
the core of pedagogical work in terms of supporting the child's development through the establishment of an intimate, caring and recognising relationship which requires comprehensive knowledge about the child. Thus, the relational rationality is a governmental rationality that is mobilised internally through a recognition approach in which the pedagogues meet the child on its own terms.

\section{The participation rationality}

Besides assessment instruments, our case institutions also select and use specific pedagogical methods independently: namely the "Marte-Meo" method and the "Pedagogy of Curiosity" method. These methods are examples of the operationalisation of a relational pedagogy that emphasises the fostering of children's well-being and self-awareness through relationships in which others recognise their participation and contribution (Papatheodorou, 2009). The first method was developed by social worker, Maria Aarts. It is based on Stern's developmental psychology, and deploys a recognising approach to the children, in which the pedagogues follow the child's initiatives and verbalise its actions (Aarts, 2005). This means that almost all everyday situations, whatever these involve, are explained by the pedagogues. For example, when the child puts clothes on in the changing room, the pedagogue will then verbalise what the child is doing, and its purpose. The goal is to provide the child with the experience of a responsive and recognising relationship with the caregiver in which the child's own initiatives and actions are acknowledged and constituted as the centre of the relationship and interactions. According to the pedagogues, the overall goal is to incorporate a positive form of contact that promotes the child's personal development in the best way possible. However, this must take its point of departure in the child's own initiatives.

The "Pedagogy of Curiosity", which was developed by one of our case institutions, is inspired by the north Italian Reggio Emilia pedagogy, and aims to incorporate the child's initiatives, creativity and curiosity into the institution's daily work and practice. Here, the child's acts are the primary focus of the pedagogical work, which typically means that the pedagogues follow the children's interests, and then challenge and develop these in collaboration with the children. Such interests may involve animals, buildings or painting, for instance.

These methods are an expression of a governmental rationality that is based upon the institution's own wishes to put the child at the centre of its pedagogical work. They are 
therefore a manifestation of the pedagogues' agency within the context of the governmental administration. The methods emphasise that it is through the child's participation, influence and active co-creation, that development and learning take place. The child's involvement has no specific goal in relation to this development and learning, but is regarded as having value in itself. Therefore, the choice of these pedagogical methods is an example of resistance to the more instrumental development rationality. This resistance is rooted in an ideal about children's participation, i.e. that children should have a voice in their own lives and in the pedagogical processes they are a part of. The pedagogues must therefore turn the power relationship around and let the child influence decisions regarding pedagogical activities. Thus, this rationality rests on democratic ideals and values: the pedagogues strive to make room for the children and let them have a say in how everyday life is organised.

\section{The ambivalence of the rationalities}

The analysis shows how the developmental rationality represents and serves a political rationality that seeks to influence the way in which the pedagogues manage children in their daily work, and shape them as future citizens. It revealed that the developmental and relational rationalities have the same objectives when it comes to ensuring age-appropriate development. This produces the reality that pedagogues must navigate, and creates certain frameworks for their relations with the children. For example, these rationalities support each other when a primary pedagogue holds formal meetings as well as informal conversations with a child's parents. These meetings and conversations serve to create a good relationship with the parents, and keep them informed about the child's life in the institution. However, at the same time, they also provide an occasion for the pedagogues to 'present' their professional assessment of the child, based upon the assessment instruments in question, as expressed in this quotation from an interview with a leader, who is describing the meetings with parents:

"It may sound a bit harsh, but then the child gets points, depending on how well it manages

[its life, development and learning]".

Here, the parents are confronted with whether or not their child displays age-appropriate development, and which competences and learning potential they should work on afterwards. One of the pedagogues described this as follows:

"For example, for the conversation, there might two different things in which the child lags behind [based on the assessment instrument], and then we can take that as a starting point [together with the parents]". 
In this way, the rationalities complement and support each other. However, there is a fundamental difference since the developmental rationality is an external political rationality that imposes the institutions' predefined goals, while the relational rationality is mobilised by the institution to make the child and its parents feel secure, albeit as a means to support and assess the child's age-appropriate development. Thus, the relational rationality appears to be subordinate to the political rationality, as the relationships are only regarded as having value if they enhance the pedagogues' ability to support the child's age-appropriate development. The risk of instrumentalising relationships is therefore imminent.

According to the participation rationality, the critical question is whether the child's emancipation and the incorporation of democratic values will, in practice, be determined by the political rationality. The leaders of the institutions emphasised that it is crucial that the pedagogues take ownership, use participatory methods and follow the children's initiatives, curiosity and creativity in designing daily activities. The activities must therefore stem naturally from the children's involvement. However, they also emphasise that the activities must relate to one of the six themes in the curriculum. Thus, children's participation is used as a means to enact the developmental rationality. This shapes and reduces children's involvement and activities in favour of supporting the curriculum. Thus, activities that are not regarded as supporting the child's development in accordance with the curriculum, i.e. that do not result in a further strengthening of the political rationality in question, are not favoured. One of the pedagogues put it this way:

"We can sit down and plan something in relation to what the children display an interest in, but it must always be in line with the curriculum themes".

When the normalised knowledge that the assessment instruments create is also internalised by the pedagogues, any emancipatory and democratic potential risks being curtailed or excluded in favour of activities that provide the prescribed level of development and learning, as preferred by the political rationality.

The relational and participation rationalities are similar in the sense that both are mobilised internally in the regime of practice. They are based on the institutions' own wishes to conduct relational pedagogical work and to create a participatory, recognising environment. However, as shown above, in practice these intentions are governed by the developmental rationality, implying that this rationality is institutionalised as the superior rationality, and the other rationalities are subordinated to the former. Within the three rationalities, there are two main 
conflicting approaches to government in practice: a divergent and a convergent mentality. The first emphasises that the child should be met with recognition and have influence over its activities. Daily life is therefore managed through recognition and democratic involvement. The second, conversely, emphasises that activities should be governed by the curriculum and developmental-psychological priorities. Thus, children are offered a subject position which on the surface seems to be characterised by recognition and participation, but which at its core is based on predefined goals and directions, and on the construction of adults (the pedagogues) as responsible for guiding the children in accordance with those goals and directions. This duality is clearly expressed in one of the leaders' descriptions of their vision for the institution:

"Our vision is that, through well-being, development and learning, we can help to create individuals who can be a part of democratic society. To show them the way and help. To create good citizens who will help to define what kind of society we want to live in".

As the quote shows, the pedagogues seek to produce and mobilise a range of capacities and characteristics in the child that are integrated through well-being, development and learning. A specific selection and exclusion mechanism is thus incorporated, whereby the understanding of citizenship is reduced to whether the child will develop and acquire the skills that are believed to be crucial to becoming a good citizen. Delanty (2003) conceptualises this approach to citizenship as governmentalisation, which shapes the citizenship learning process in a disciplining manner, with the risk of producing alienation and exclusion. Thus, although the relational and participation rationalities in our case do not rest on specific objectives for development and learning, nor are they intended to normalise the child, in practice when these rationalities are used to fulfil the political rationality they become an instrument to realise other objectives.

\section{Discussion}

In this study, we have revealed certain rationalities in the pedagogical regime of practice in Denmark. This creates an opportunity to question and criticise the way in which children are subjected to different rationalities of government. The study did not intend to follow a genealogical trail or to unravel historically how these rationalities have developed in relation to children and childhood. Many others have already done this and demonstrated that rationalities shift over time, which creates certain ways of thinking about children and 
constructs power relations between children and adults (Hultqvist, 1997; James et al., 1998; Vandenbroeck \& Bouverne-De Bie, 2006; Smith, 2011; 2014). Instead, our starting point was the pedagogical regime of practice, as exemplified in two day care institutions. The intention was not to analyse everyday life, but to explore how rationalities create a specific frame for the regime of practice. Our study goes beyond existing approaches to studying the normalisation of children in the educational system and the ways in which developmental psychology affects this system, since it also includes day care services in Denmark, and children aged 0-6.

We conclude that the dominant rationality is the developmental rationality, and that the relational and participation rationalities are regarded as instruments to realise this. This creates a certain framing of daily work, as care relations become instrumentalised and certain activities are omitted because they do not support the objectives of the political rationality. This is not necessarily a problem, though, as prioritising children's development and learning may be crucial for the individual child. However, we do see a risk that problems may arise if this priority becomes so dominant that all other ideals and values are subordinated to it. For instance, if involvement and recognising relations are instrumentalised, this could potentially lead to the standardisation of pedagogical work, as well as of the children who are its targets. When institutions use assessment instruments that create a normalised understanding of development, some capacities and skills are nursed and fostered while other ways of behaving that are considered flawed, or deviations from 'normal' behaviour, are monitored and corrected. Although the staff at our case institutions are reflexive about their pedagogy, they are not aware of how the assessment tools they have chosen themselves mobilise the political agenda in a way that undermines their own pedagogical values and goals. Thus our analysis reinforces Millei \& Kallio's point that "professionals could be more aware of the political agendas they mobilizse as part of their pedagogies and caring work" (2016: 13), by highlighting the power of seemingly 'innocent' and helpful tools in the shaping of the practice regime. In another study, Houmøller (2018) also problematises the use of so-called "well-being assessment tools"; however, her criticism is that these create a false sense of security about children's well-being, causing some children to become invisible in pedagogical practice.

Our analysis of different rationalities also identifies a subject position in which children have to play a deliberate and active part in their own learning and evolution, but are at the same time subject to moulding based on various normalising techniques and knowledge about how children normally develop. Similarly, Ailwood $(2004 ; 2008)$ shows how children are prepared 
for a life of lifelong learning and earning; and Redmond (2010) finds that children are regarded as experts in their own lives. However, our study indicates that this is only the case to a limited extent because the developmental rationality constructs the pedagogues as knowledgeable and responsible.

Why should we be interested in these rationalities, and in how power is exercised in day care institutions? First of all, because such an analysis shows how freedom-based power is constituted and how it guides the pedagogues towards a certain way of thinking and behaving in relation to the children and the way the children are involved. Second, because power can be changed and modified, the rights that protect children, for example the UN Convention on the Rights of the Child, cannot guarantee that power will not turn into a relationship of domination. If children's rights to participation, through their daily involvement and freedom of speech, are reduced to whether their involvement fulfils political objectives concerning the mobilisation of specific competences, children will become locked into a subordinate position that does not correspond to the rights and conditions that the Convention promotes. This suggests a further need to analyse the presence of the various, and often conflicting, rationalities in practice, with a view to clarifying how dominant rationalities subordinate alternative approaches.

\section{References}

Aarts M (2005) Marte Meo: En grundbog. Hindholm Socialpædagogiske Seminarium, Fuglebjerg: Aarts Productions.

Ailwood J (2004) Genealogies of Governmentality: Producing and Managing Young Children and Their Education. The Australian Educational Researcher 31(3): 19-33.

Ailwood J (2008) Learning or earning in the 'Smart State': Changing tactics for governing early childhood. Childhood 15(4): 535-551.

Alanen L (2009) Generational order. In Qvortrup J, Corsaro W and Honig M (eds.) The Palgrave Handbook of Childhood Studies . Houndsmills, Basingstoke, Hampshire: Palgrave Macmillan. 
Bahle T (2009): Public Child Care in Europe: Historical Trajectory and New Directions. In Scheiwe \& Willekens (eds.). Child Care and Preschool Development in Europe: Institutional Perspectives. Basingstoke: MacMillan: 23-43.

Broström S (2008) Pædagogiske læreplaner i børnehaven. In Broström S (eds) Pcedagogiske loereplaner - at arbejde med didaktik i børnehaven. Academica. 27-49.

Buhler-Niederberger D \& H Sunker (2009) Interest in and responsibility for children and their life-worlds. In Qvorturp J, Corsaro W \& Honig M (eds) The Palgrave Handbook of Childhood Studies. Houndsmills: Palgrave Macmillan: 394-407.

Cerny P G (2010) The Competition State Today: From Raison d'État to Raison du Monde. Policy Studies. 31(1), 5-21.

Dahlberg G and Moss P (2005) Ethics and Politics in Early Childhood Education. Abingdon, Routledge Falmer.

Dean M (1999) Governmentality - Power and Rule in Modern Society. SAGE Publications.

Delanty G (2003) Citizenship as a learning process - Disciplinary citizenship versus cultural citizenship. Lifelong Education, 22(6): 597-605.

Devine D \& Kilkelly U (2011) Nordic childcare model best for economic and social wellbeing. The Irish Times June the $9^{\text {th }}$. https://www.irishtimes.com/opinion/nordicchildcare-model-best-for-economic-and-social-wellbeing-1.591772

Esping-Andersen G with D Gallie, A Hemerijck \& J Myles (2002) Why we need a New Welfare State. Oxford: Oxford University Press.

Fendler L (2001) Educating Flexible Souls: The Construction of Subjectivity through Developmentality and Interaction. In Hultqvist K and Dahlberg G (eds) Governing the Child ind The New Millennium. Routledge, pp. 119-142. 
Flyvbjerg B (2006) Five misunderstandings about case-study research. Qualitative Inquiry 12(2): 219-245.

Foucault M (1983) The subject and power. In Dreyfus H and Rabinow P (eds) Michel Foucault: Beyond Structuralism and Hermeneutics. The University of Chicago Press, pp. 208-226.

Foucault M (1984) The ethic of care of the self as a practice of freedom. In Bernauer J and Rasmussen D (eds) The Final Foucault. Cambridge, MA, London: The MIT Press, pp. 1-20.

Foucault M (1991) Governmentality. In Burchell G et al. (eds) The Foucault Effect. The University of Chicago Press, pp. 87-104.

Foucault M (1991a) Questions of method. In Burchell G et al. (eds) The Foucault Effect. The University of Chicago Press, pp. 73-86.

Froebel F (1985) Friedrich Froebel's Pedagogics of the Kindergarten: Or, His Ideas Concerning the Play and Playthings of the Child. New York: D. Appleton: 244-246.

Giddens A (1998) The Third Way. The renewal of social democracy. Cambridge: Polity Press.

Goffman E (1961) Asylums: Essays on the Condition of the Social Situation of Mental Patients and Other Inmates. Anchor Books.

Haldar and Engebretsen (2014) Governing the liberated child with self-managed family displays. Childhood 21(4): 475-487.

Houmøller K (2018) Making the invisible visible? Everyday lived experiences of 'seeing' and categorizing children's well-being within a Danish kindergarten. Childhood 25(4): 488500 . 
Hultqvist K (1997) Changing Rationales For Governing the Child: A Historical Perspective on the Emergence of the Psychological Child in the Context of Preschool - Notes on a Study in Progress. Childhood 4(4): 405-24.

Hultqvist K and Dahlberg G (eds) (2001) Governing the Child in the New Millennium. London: Routledge Falmer.

James A et.al. (1998) Theorizing Childhood. Cambridge: Polity Press.

Jessop, B (2002). The Future of the Capitalist State. Cambridge, Oxford \& Malden: Polity Press.

Kampmann J \& Nielsen H W (2004) Children's Childhoods in Denmark: Socialized Childhood. In A-M Jensen et al. (eds.) Children's Welfare in Ageing Europe. Vol II, Tronheim: NOSEB.

LearnLab (2019) Generel information om Kompetencehjulskonceptet. At: https://www.learnlab.dk/index.php?id=9663 (accessed 13 March)

Lee N (2001) Childhood and Society: Growing Up in an Age of Uncertainty. Maidenhead: Open University Press.

Lee N and Motzkau J (2011) Navigating the bio-politics of childhood. Childhood 18(1) 7-19.

Lister R (2004) The Third Way’s Social Investment state. In J Lewis \& R Surender (eds.) Welfare State Change: Towards a third way? Oxford: Oxford University Press: 157-181

Miller P and Rose N (1990) Governing economic life. Economy and Society 19(1): 1-31.

Millei Z \& K P Kallio (2016) Recognizing politics in the nursery: Early childhood education institutions as sites of mundane politics. Contemporary Issues in Early Childhood 19(1) 3147. 
Parton N (1998) Risk, Advanced Liberalism and Child Welfare: The Need to Rediscover Uncertainty and Ambiguity. British Journal of Social Work 28(1): 5-27.

Qvortrup J (2009) Childhood as a Structural Form. In Qvortrup J, Corsaro W \& Honig M (eds.) The Palgrave Handbook of Childhood Studies. Palgrave Macmillan: 21-33.

Redmond G (2010) Children's agency and the welfare state: Policy priorities and contradictions in Australia and the UK. Childhood 17(4): 470-484.

Reksten P M \& S S Jørgensen (1996) Fremtidens børneinstitution: Fra pasning til udvikling. København: Mandag Morgen Strategisk.

Retsinformation (2015) Bekendtgørelse af lov om dag-, fritid- og klubtilbud m.v. til børn og unge. At: https://www.retsinformation.dk/forms/r0710.aspx?id=168340 (accessed 2 February 2017)

Retsinformation (2015a) Vejledning om dagtilbud m.v. At: https://www.retsinformation.dk/Forms/R0710.aspx?id=168574 (accessed 2 February 2017)

Rose N and Miller P (1992) Political Power beyond the State: Problematics of Government. The British Journal of Sociology 43(2): 1771-205.

Rose N (1999) Powers of Freedom: Reframing political thought. Cambridge University Press.

Siigsgaard E, K Rasmussen \& S Smith (1998) Andre måder. København: Hans Reitzels Forlag.

Smith K (2011) Producing governable subject: Images of childhood old and new. Childhood 19(1): 24-37.

Smith K (2014) The Government of Childhood: Discourse, Power and Subjectivity. Palgrave Macmillan. 
Stern D (1995) Barnets interpersonelle univers. Hans Reitzels Forlag.

Sylva K (2010) Foreword. In D Sommer, I P Samuelsson \& K Hundeide (eds.) Child Perspectives and Children's Perspectives in Theory and Practice. Dordrecht, Heidelberg, London \& New York: Springer: v-viii.

Vandenbroeck M \& M Bouverne-De Bie (2006) Children's agency and educational norms A tensed negotiation. Childhood 13(1): 127-143.

Warming, H. (2011): Børneperspektiver: Børn som ligevardige medspillere i paedagogisk og socialt arbejde. København: Akademisk Forlag.

Warming H (2018a) Children's citizenship in globalized societies. In C Baraldi \& T Cockburn (eds.) Theorizing Childhood: Citizenship, Rights, and Participation. Palgrave Macmillan: 29-52.

Warming, H. (2018b): “Trust and power dynamics in children's lived citizenship and participation in globalized societies.” Children \& Society. DOI: 10.1111/chso.1231

Wedel-Brandt B (2008) Daniel Sterns teori om udvikling. In Jerlang E (eds) Udviklingspsykologiske teorier. Hans Reitzels Forlag, pp. 420-456.

Wyness M (2018) Children's Participation: Definitions, Narratives and Disputes. In C Baraldi \& T Cockburn (eds.) Theorizing Childhood: Citizenship, Rights, and Participation. Palgrave Macmillan: 53-72. 